\title{
Titanium for Long-Term Tritium Storage (U)
}

by

L. K. Houng

Westinghouse Savannah River Company

Savannah River Site

Aiken, South Carolina 29808

\section{DISCLAIMER}

\begin{abstract}
This report was prepared as an account of work sponsored by an agency of the United States Government. Neither the United States Government nor any agency thereof, nor any of their employees, makes any warranty, express or implied, or assumes any legal liability or responsibility for the accuracy, completeness, or usefulness of any information, apparatus, product, or process disclosed, or represents that its use would not infringe privately owned rights. Reference herein to any specific commercial product, process, or service by trade name, trademark, manufacturer, or otherwise does not necessarily constitute or imply its endorsement, recommendation, or favoring by the United States Government or any agency thereof. The views and opinions of authors expressed herein do not necessarily state or reflect those of the United States Government or any agency thereof.
\end{abstract}

DOE Contract No. DE-AC09-89SR18035

This paper was prepared in connection with work done under the above contract number with the U.S.

Department of Energy. By acceptance of this paper, the publisher and/or recipient acknowledges the U.S.

Government's right to retain a nonexclusive, royalty-free license in and to any copyright covering this paper, along with the right to reproduce and to authorize others to reproduce all or part of the copyrighted paper. 


\section{DISCLAIMER}

Portions of this document may be illegible in electronic image products. Images are produced from the best available original document. 


\title{
Titanium For Long Term Tritium Storage (U)
}

\author{
by
}

L. K. Heung

December 1994

K.K. Hewng

L. K. Heung, Author

Process Technology Group

Hydrogen Technology Section
$12 / 19 / 94$

Date

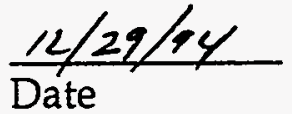

T. Motyka, Manager \&

Authorized Derivative Classifier

Process Technology Group

Hydrogen Technology Section

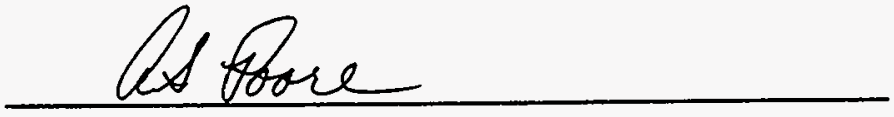

Technical Reviewer

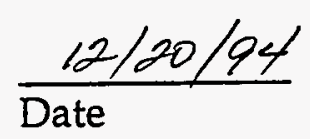


WSRC-TR-94-0596

Page 1 of 14

\author{
Titanium For Long Term Tritium Storage \\ by \\ L. K. Heung \\ December 1994
}

\title{
Introduction
}

Due to the reduction of nuclear weapon stockpile, there will be an excess of tritium returned from the field. The excess tritium needs to be stored for future use, which might be several years away. A safe and cost effective means for long term storage of tritium is needed. Storing tritium in a solid metal tritide is preferred to storing tritium as a gas, because a metal tritide can store tritium in a compact form and the stored tritium will not be released until heat is applied to increase its temperature to several hundred degrees centigrade. Storing tritium as a tritide is safer and more cost effective than as a gas.

Several candidate metal hydride materials have been evaluated for long term tritium storage. They include uranium, La-Ni-Al alloys, zirconium and titanium. The criteria used include material cost, radioactivity, stability to air, storage capacity, storage pressure, loading and unloading conditions, and helium retention. Titanium has the best combination of properties and is recommended for long term tritium storage.

\section{Summary}

- Literature information on titanium-hydrogen (and tritium) systems has been reviewed. Titanium is a low cost metal that can absorb and store tritium in a compact solid form at a very low tritium pressure of about $1 \mathrm{E}-7$ torr. Titanium retains the decay helium up to a concentration of $0.3 \mathrm{He}$ atom per $\mathrm{Ti}$ atom. The number of years required to build up this helium concentration is dependent on the tritium concentration in the hydrogen isotopes stored in the titanium. It increases from a minimum of 3 years for pure tritium to 24 years for $20 \%$ tritium, in a fully charged titanium bed $[(T+D+H) / T i=2]$. Longer times are achieved by diluting the tritium concentration with its isotopes, deuterium or protium. Titanium tritide is stable in air and does not release the tritium until it is heated to very high temperatures.

- A preliminary design of a titanium vessel for long term tritium storage has been proposed. The overall dimension of the vessel is about 6.7" OD by 16" high, and weighs about 35 Lbs. It contains $4.4 \mathrm{~kg}$ of titanium and has a capacity for 400 grams of tritium if charged with pure tritium to $1.5 \mathrm{~T} / \mathrm{Ti}$, or for 200 grams if $1 / 2$ of the tritium is replaced with deuterium or protium. The 
helium retention time will be 4 years for pure tritium and 8 years at a $50 \%$ concentration.

- Compared with La-Ni-Al and uranium, titanium costs 1/40 of that of LANA and about $1 / 5$ of that of uranium. Titanium is safer to use than both LANA and uranium, because it is stable in air. The tritium pressure in a titanium vessel is 10 orders lower than that of LANA and 4 orders lower than that of uranium. The only disadvantage of titanium is that it requires a higher temperature to desorb the tritium than the other two systems.

\section{Recommendations}

1. Titanium should be the choice for long term tritium storage, because it is a low cost material and has key advantages over the other materials considered.

2. The path forward on technical development should include:

- Develop titanium specifications based on factors such as cost, form, impurity level, hydriding/dehydriding properties and availability.

- Produce data of the titanium-hydrogen (and tritium) to confirm the literature information.

- Fabricate and test a production prototype to optimize activation, charging and discharging operations, and to determine vessel wall stress behavior.

\section{Properties of Titanium}

Titanium is the ninth most abundant element in the earth's crust, about 5 times less than iron but 100 times greater than copper ${ }^{1}$. Its current cost is between $\$ 5$ $\$ 20 / \mathrm{Lb}$ dependent on grade and quantity. Titanium is available in a sponge form and a dense metal form. Titanium sponge comes in different particle sizes and has a bulk densities from about 1 to $1.5 \mathrm{~kg}$ per liter. Titanium metal weighs about $4.5 \mathrm{~kg} /$ liter. The physical properties of titanium useful to this application are given in Table 1.

\section{Titanium-Hydrogen System}

The titanium-hydrogen system has been studied by several authors ${ }^{2,3}$. An isotherm plot of pressure, temperature and concentration is shown in Figure 1. Titanium can react with hydrogen to form three different phases of titanium hydrides, ${ }^{6}$ with a maximum hydrogen content of about 2 atoms of hydrogen per 
each titanium atom. The phases are formed according to the temperature and hydrogen concentration. As the titanium takes in hydrogen, an $\alpha$ phase forms first. When the hydrogen concentration reaches about $0.08 \mathrm{H} / \mathrm{Ti}$, the $\delta$ phase appears if the temperature is below about $300^{\circ}$, or the $\beta$ phase appears if the temperature is above $300{ }^{\circ} \mathrm{C}$. The $\beta$ phase begins to convert to the $\delta$ phase at about $1 \mathrm{H} / \mathrm{Ti}$, and the conversion is complete at about $1.5 \mathrm{H} / \mathrm{Ti}$.

Therefore, at temperatures above $300{ }^{\circ} \mathrm{C}$, there are two 2-phase regions, the ( $\alpha+$ $\beta)$ and the $(\beta+\delta)$ region. At temperature below $300{ }^{\circ} \mathrm{C}$ there is only one 2-phase region, the $(\alpha+\delta)$ region. The pressure in the 2-phase regions changes slowly when the hydrogen concentration changes. From the data given in reference 3, the following two van't Hoff equations have been derived to represent the pressure as a function of temperature in the 2-phase regions:

For the $(\alpha+\beta)$ region $(\mathrm{H} / \mathrm{Ti}=0.1$ to 0.4$)$,

$$
\ln P=-19692.4 /\left(R^{*} T\right)+11.5 / R
$$

For the $(\beta+\delta)$ region $(\mathrm{H} / \mathrm{Ti}=1$ to 1.5$)$,

$$
\ln \mathrm{P}(\mathrm{atm})=-39257.5 /\left(\mathrm{R}^{*} \mathrm{~T}\right)+42.9 / \mathrm{R}
$$

where $\quad \mathrm{P}=$ absorption or desorption pressure, atm

$$
\mathrm{T}=\text { temperature, }{ }^{\circ} \mathrm{K}
$$

$\mathrm{R}=$ gas constant, $1.986, \mathrm{cal} / \mathrm{g}-\mathrm{mol} \mathrm{H}_{2} /{ }^{\circ} \mathrm{K}$

There was not sufficient data to develop an equation for the $(\alpha+\delta)$ region, but its pressure should be bound by the above two equations. Equations 1 and 2 are plotted in Figure 2. Note that the intersect of the two line defines the temperature $\left(\sim 300^{\circ} \mathrm{C}\right)$ and pressure below which the $\beta$ phase does not exist. At 25 ${ }^{\circ} \mathrm{C}$ room temperature, the equilibrium pressure calculated via equation 1 is $1.16 \mathrm{E}$ $12 \mathrm{~atm}$ (or $8.8 \mathrm{E}-10$ torr).

\section{Tritium Capacity}

According to the isotherm data, titanium can absorb hydrogen up to about 2 atoms of $\mathrm{H}$ per atom of $\mathrm{Ti}$. The capacity for protium and that for tritium are expected to be about the same. Researchers have charged titanium films with pure tritium to $1.9 \mathrm{~T} / \mathrm{Ti} 4$, and with tritium and deuterium mixtures to 1.62 $(\mathrm{T}+\mathrm{D}) / \mathrm{Ti} 5$. The capacity data for protium should apply to tritium for all practical purposes. 


\section{Helium Retention}

Helium retention by titanium has been studied by several authors. $4,5,7,8,9$ Titanium saturated with tritium and stored at room temperature retained the decay helium until the helium content is $0.3 \mathrm{He} / \mathrm{Ti}$. After that the helium release rate is equal to the helium production rate by tritium decay. At tritium storage conditions, that is, temperature below $300{ }^{\circ} \mathrm{C}$ and tritium in the $\delta$ phase $[(\mathrm{T}+\mathrm{D}+\mathrm{H}) / \mathrm{Ti} \geq 1.5]$, the number of years before the decay helium begins to release can be calculated by the following equation:

$$
\mathrm{He} / \mathrm{Ti}=0.3=\mathrm{T} / \mathrm{Ti} *[1-\exp (-0.0563 * \mathrm{t})] \quad \text { for }(\mathrm{T}+\mathrm{D}+\mathrm{H}) / \mathrm{Ti}=1.5 \text { to } 2
$$

where

$\mathrm{t}=$ years after which the decay helium releases.

With equation (3) table 2 is calculated. The results show that the number of years before the helium releases can be extended by diluting the concentration of tritium by protium or deuterium. This phenomenon is supported by theory and experimental data presented in Reference 5. Table 2 shows that the years before helium release can be over 20 years. The shortest time is about 3 years when the tritium concentration is $2 \mathrm{~T} / \mathrm{Ti}$.

\section{Helium Removal}

Helium retained in the titanium can be recovered by heating and evacuation. The rates of helium evolution from titanium samples of different helium concentrations were studied and reported in Reference 7 . The data shows that the helium evolution rate is a function of both helium content and temperature. High helium content requires a low temperature to remove the helium. When the helium content is higher than about $0.4 \mathrm{He} / \mathrm{Ti}$, the evolution rate becomes significant at temperatures as low as $200^{\circ} \mathrm{C}$. But a minimum temperature of 700 ${ }^{\circ} \mathrm{C}$ is required to remove the helium when the concentration is about $0.3 \mathrm{He} / \mathrm{Ti}$ and below. The required temperature increases to about $1000^{\circ} \mathrm{C}$ when the concentration decreases to about $0.2 \mathrm{He} / \mathrm{Ti}$, and to about $1400{ }^{\circ} \mathrm{C}$ if the concentration is less than $0.1 \mathrm{He} / \mathrm{Ti}$.

\section{Stability of Titanium Hydride}

The stability of titanium hydride and tritide, in air and in water has been studied.10, 11 Titanium hydrides and tritides are not pyrophoric in air at room temperature, and are stable in air at temperatures up to about $800^{\circ} \mathrm{C}$ dependent on particle size. Samples of titanium hydride prepared from sponge did not burn at any temperature up to $800^{\circ} \mathrm{C} .10$ The hydride or tritide of titanium is brittle and 
tends to become finer as it undergoes physical shock. Finer particles are expected to be less stable than large particles. Tests showed that titanium hydrides that had undergone 10 absorption/desorption cycles and physical agitation for a number of weeks showed less than $10 \%$ of the material in the $<38 \mu \mathrm{m}$ range. These fine particles did not ignite until the temperature was $420^{\circ} \mathrm{C} .11$

Titanium tritide is also stable in water. Leaching tests of $\operatorname{TiT}_{1.8}$ showed a total tritium release of about $1 \mathrm{E}-5$ fraction over 150 days. 11

\section{Vessel Design}

A design similar to, but larger than the hydride transport vessel (HTV) ${ }^{12}$ is proposed for this long term tritium storage application. Larger vessels will reduce the number of vessels required for the large quantity of expected tritium. But the vessel must not be too large or too heavy so that it can be easily handled manually and can pass through the air locks of existing gloveboxes.

A schematic of the design is shown in Figure 3. The vessel consists of a container body, which is formed by welding together a 4-inch long section of 6 inch schedule 40 stainless steel pipe, and two 6 inch schedule 40, stainless steel pipe caps. The container is filled with $4.4 \mathrm{~kg}$ of titanium sponge particles (or titanium metal chips or turnings) before closing. Two pieces of stainless steel tubing penetrate the top cap of the container body serve as inlet and outlet for the flow of gases. The open ends of the tubes are welded on with porous stainless steel filters, 2 to 5 micron pore size, to prevent any of the titanium particles from escaping the container. A welded bellows sealed, stainless steel valve welded in each of the tubes is used for closing and opening the container. To minimize the temperature at the valves during heating, the length of the tubes between the valves and the top of the container body should be maximized by bending the tubes. A handle and valve guard is welded to the top of the container to protect the valves and tubes from direct impacts.

An electric furnace of proper design is recommended for the heating of the vessel during activation and tritium removal operations. The vessel can be placed in the upright or horizontal position, dependent on the desired arrangements of the operating manifold and the furnace.

\section{Operation}

Operation of the vessel can be divided into several steps: activation charging, storage, discharging, preparation for disposal, and helium removal. 
Activation:

The titanium must be activated before it can absorb tritium readily. Activation can be accomplished by heating the titanium to about $600{ }^{\circ} \mathrm{C}$ for about 2 hours under vacuum to remove volatile impurities and oxides from the titanium surfaces. To increase the activity, the evacuation may be followed by exposing the titanium to protium (or deuterium if protium residue is not desirable) at about one atm pressure until saturation. This hydrogen exposure can be done at temperatures between 200 to $600{ }^{\circ} \mathrm{C}$. The absorbed protium or deuterium is then desorbed from the titanium by evacuation and heating at about $600{ }^{\circ} \mathrm{C}$. The valves are closed and the container is cooled down to room temperature to end the activation treatment. The container is then ready for tritium charging.

\section{Charging}

The vessel should always be charged to a concentration of total hydrogen isotopes $[(\mathrm{H}+\mathrm{D}+\mathrm{T}) / \mathrm{Ti}]$ of more than 1.5 . The fraction of tritium in the mixture of isotopes will be dependent on the storage time desired when the titanium is saturated with helium. This fraction can be calculated by applying equation 3 (or Table 2). For example, the $\mathrm{T} / \mathrm{Ti}$ values of $0.6,0.8,1.0,1.5$ and 2.0 will give storage time of about $12,8,6,4$ and 3 years, respectively, before the titanium is saturated with helium. And the quantities of tritium stored in the $4.4 \mathrm{~kg}$ of titanium will be $165,220,275,413$ and 550 gram, respectively.

To charge tritium or tritium and deuterium (or protium) mixtures into the container, connect the container to the gas source via one of the valves. The hydrogen isotopes will be absorbed readily by the activated titanium at room temperature. The absorption is an exothermic (heat producing) reaction and will produce between 20 to $40 \mathrm{kcal} / \mathrm{mole}$ of hydrogen absorbed. The heat will warm up the container and then dissipate to the ambient. At equilibrium the tritium pressure at room temperature will be less than about $10^{-9}$ torr.

Titanium does not absorb helium or other inert gases. These gases, if they are in the feed gas, can accumulate and blanket the titanium from absorbing the hydrogen. In such cases, the two inlet/outlet ports can be connected in a flowthrough mode. In this mode the gas flows in via one of the two ports, passes through the titanium and flows out via the other port. The hydrogen isotopes are absorbed while the gas is passing through the titanium, but the inerts will just pass through. In this way the inerts are separated from the hydrogen isotopes, and the loading time is shortened.

\section{Storage}

After charging, the vessel can be moved and stored in a safe place. But the vessel will not be designed and certified to be moved on public roads. The storage space must be properly ventilated to avoid excessive accumulation of tritium decay heat. The ventilation should be able to keep the titanium tritide temperature at 
less than about $100{ }^{\circ} \mathrm{C}$ to maintain a low tritium vapor pressure and to avoid the creation of hot surfaces for personnel safety.

\section{Discharging,}

Tritium stored in titanium will be recovered (discharged) by heating and evacuation. Based on the equilibrium isotherms, the percentage of hydrogen isotopes that can be directly removed by heat and vacuum is a function of temperature and pressure. Table 3 shows the estimated percentage of removed hydrogen as a function of temperature and pressure for a storage vessel charged to a total hydrogen concentration of $1.8(\mathrm{H}+\mathrm{D}+\mathrm{T}) / \mathrm{Ti}$. A discharge temperature of $600{ }^{\circ} \mathrm{C}$ and a vacuum of 1 torr are required in order to recover $95 \%$ of the hydrogen isotopes in a reasonable amount of time. The rest of the tritium that cannot be directly recovered by heat and evacuation, can be recovered by isotope exchange at about $500{ }^{\circ} \mathrm{C}$. The number of exchanges required will be dependent on several variables that include the amount of tritium to be exchanged, the amount of deuterium (or protium) used in each exchange and how complete a recovery is desired. Five to 10 exchanges with about $20 \%$ of capacity gas will normally reduce the residual tritium concentration by a factor of 10 .

\section{Preparation for Disposal}

The vessel should be designed for one-time use only. After the residual tritium has been reduced to the acceptable level by isotope exchange, the vessel will be disposed of as low level solid waste by established procedures. The main reason for one-time use is that after heating to $600{ }^{\circ} \mathrm{C}$ in the presence of tritium, the wall of the vessel will most likely be saturated with tritium at the equilibrium level with the tritium pressure. This can cause surface contamination and also weaken the vessel wall.

\section{Helium Removal}

If desired, the helium retained in the titanium can be recovered by heat and evacuation. The rates of helium evolution from titanium samples of different helium concentrations were measured and reported in Reference 7. The data showed that the temperature required to remove the retained helium increases as the helium concentration decreases. A minimum temperature of $700{ }^{\circ} \mathrm{C}$ is required to remove helium when the concentration is $0.3 \mathrm{He} / \mathrm{Ti}$. The required temperature increases to about $1000^{\circ} \mathrm{C}$ when the concentration decreases to 0.2 $\mathrm{He} / \mathrm{Ti}$. A temperature of up to $1400^{\circ} \mathrm{C}$ will be required to remove the helium if the concentration is less than $0.1 \mathrm{He} / \mathrm{Ti}$.

\section{Canadian Data}

Ontario Hydro of Canada has developed and implemented a tritium immobilization system using titanium. Some of their results have been 
published and can be found in References 11, 13, and 14. These data support our choice of titanium for long term tritium storage.

\section{Comparison with LANA (La-Ni-Al) and Uranium}

The advantages and disadvantages of using titanium, LANA.85 ( $\left.\mathrm{LaNi}_{4.15} \mathrm{Al}_{0.85}\right)$ or uranium for long term tritium storage have been briefly compared before in Reference 15. A more complete comparison is given in Table 4. The comparison clearly shows that titanium is the better choice for tritium long term storage. Another low pressure hydride, the zirconium hydride, has a very low hydrogen pressure, about 1,000 times lower than that of titanium hydride. Tritium stored in zirconium will require a much higher temperature to desorb, and therefore not desirable.

\section{References}

1. "Encyclopedia of Chemical Technology", vol. 23, p98, 1983.

2. A. D. McQuillan, "An experimental and thermodynamic investigation of the hydrogen-titanium system", Proc. Roy. Soc. (London) Ser. A, 204:313, 1953.

3. W. M. Mueller, in "Metal Hydrides", Academic Press, NY, 1968.

4. W. G. Perkins, W. J. Kass and L. C. Beavis, "3He Release Characteristics of Metal Tritides and Scandium-Tritium Solid Solutions", in "Radiation Effects and Tritium Technology for Fusion Reactors", CONF-750989 vol. IV, March, 1976.

5. P. Bach, "Comparison of Theoretical and Experimental $3 \mathrm{He}$ Desorption Behavior of Titanium Tritide Films", Radiation Effects, 1983, Vol. 78, pp. 7786.

6. T. B. Massalski, Editor-in-chief, "Binary Alloy Phase Diagrams", 2nd edition, vol. 2, p 2066, 1990.

7. A. M. Rodin and V. V. Surenyants, "Solid Solutions of Helium in Titanium Containing Up to 30 at.\% of Helium", Russian Journal of Physical Chemistry, 45(5), 1971.

8. L. C. Beavis and W. J. Kass, "Room-temperature desorption of ${ }^{3} \mathrm{He}$ from metal tritides: A tritium concentration effect on the rapid release of helium from the tritide", J. Vac. Sci. Technol., Vol. 14, No 1, Jan./Feb. 1977.

9. Pierre Bach, "Improvement of the room-temperature behavior of metal tritides with respect to ${ }^{3} \mathrm{He}$ release: Titanium", Appl. Phys. Lett. 37(5), 1 September 1980.

10. J. M. Yaraskavitch and W. J. Holtslander, "Storage of Tritium in Metal Hydrides", MIAMI International Symposium on Metal-Hydrogen Systems, 619-632 (1981).

11. W. J. Holtstander, et al, "Recovery and Packaging of Tritium from Canadian Heavy Water Reactors", Fusion Technology, vol. 8, September 1985. 
12. M. N. Van Alstine, "SRS H1616 Hydride Transport Vessel Qualification Report", WSRC-RP-92-1161.

13. S. K. Sood, R. A. P. Sissingh and O. K. Kveton, "Removal and Immobilization of Tritium From Ontario Hydro's Nuclear Generation Stations", Fusion Technology. vol. 8, September 1985.

14. N. P. Kherani and W. T. Shmayda, "Gas Handling Systems Using TitaniumSponge and Uranium Bulk Getters", Fusion Technology, vol. 8, September, 1985.

15. L. K. Heung, "Stockpile Reduction Review Team - Long Term Tritium Storage", SRL-HTS-92-0065.

Table 1 Physical Properties of Titanium.

\begin{tabular}{ll}
\hline Property & Value \\
\hline & 47.9 \\
Atomic weight & 1 to $1.5 \mathrm{~kg} /$ liter \\
Sponge bulk density & $4.5 \mathrm{~kg} / \mathrm{liter}$ \\
Metal density & $16688^{\circ} \mathrm{C}$ \\
Melting point & $21.9 \mathrm{~W} / \mathrm{m} / \mathrm{K}$ \\
Thermal conductivity at $25^{\circ} \mathrm{C}$ & $\left(21.9 / 1.73=12.66 \mathrm{Btu} / \mathrm{h} / \mathrm{ft} /{ }^{\circ} \mathrm{F}\right)$ \\
& $536.3 \mathrm{~J} / \mathrm{kg} /{ }^{\circ} \mathrm{C}$ \\
Specific heat at $25^{\circ} \mathrm{C}$ & $\left(536.3 / 4190=0.128 \mathrm{Btu} / \mathrm{LB} /{ }^{\circ} \mathrm{F}\right)$ \\
& \\
\hline
\end{tabular}


Table 2 Decay Helium Retention in Titanium.

\begin{tabular}{|c|c|c|}
\hline $\begin{array}{c}\text { Total Hydrogen } \\
\text { Concentration } \\
(\mathrm{T}+\mathrm{D}+\mathrm{H}) / \mathrm{Ti}\end{array}$ & $\begin{array}{c}\text { Tritium } \\
\text { Concentration } \\
\mathrm{T} / \mathrm{Ti}\end{array}$ & $\begin{array}{l}\text { Years Before } \\
\text { Helium Release }\end{array}$ \\
\hline 1.5 to 2 & 0.4 & 24.62 \\
\hline 1.5 to 2 & 0.6 & 12.31 \\
\hline 1.5 to 2 & 0.8 & 8.35 \\
\hline 1.5 to 2 & 1 & 6.34 \\
\hline 1.5 to 2 & 1.2 & 5.11 \\
\hline 1.5 to 2 & 1.4 & 4.28 \\
\hline 1.5 to 2 & 1.5 & 3.96 \\
\hline 1.5 to 2 & 1.6 & 3.69 \\
\hline 1.5 to 2 & 1.8 & 3.24 \\
\hline 1.5 to 2 & 2 & 2.89 \\
\hline
\end{tabular}

Table 3. Tritium Discharging Rate From Titanium Tritide.

\begin{tabular}{cccc}
\hline $\begin{array}{c}\text { Temperature } \\
{ }^{\circ} \mathrm{C}\end{array}$ & $\begin{array}{c}\text { Pressure } \\
\text { torr }\end{array}$ & $\begin{array}{c}\text { Discharged } \\
\%\end{array}$ & $\begin{array}{c}\text { Estimated Rate* } \\
\text { Liter(STP)/hr }\end{array}$ \\
\hline 530 & 40 & 55 & 190 \\
530 & 1 & 95 & 12 \\
590 & 180 & 55 & 370 \\
590 & 2.2 & 95 & 32
\end{tabular}

\footnotetext{
${ }^{*}$ A 9 CFM Normetex pump backed by a metal bellows pump is used for the rate calculation:

Liter(STP) $/ \mathrm{hr}=$ pressure $\mathrm{X}$ pump rate $/ 760 \times 270 / 298$

pump rate is from pump performance data.
} 
Table 4. Comparison of Titanium, LANA.85 and Uranium for Long Term Tritium Storage.

\begin{tabular}{|c|c|c|c|}
\hline & Titanium & LANA.85 & Uranium \\
\hline Cost, $\$ / \mathrm{kg}$ & 10 & 400 & 50 \\
\hline \multicolumn{4}{|l|}{ Tritium capacity } \\
\hline $\begin{array}{l}\mathrm{g}-\mathrm{mole} / \mathrm{kg} \\
\text { atom ratio } \mathrm{T} / \mathrm{M}\end{array}$ & $\begin{array}{c}19 \\
(1.8)\end{array}$ & $\begin{array}{c}5.2 \\
(0.7)\end{array}$ & $\begin{array}{l}6.3 \\
(3)\end{array}$ \\
\hline \multicolumn{4}{|l|}{ Helium retention } \\
\hline $\mathrm{He} / \mathrm{Ti}$ & 0.3 & $>0.2$ & 0.16 \\
\hline Years@ full capacity & 4 & $>6$ & 1 \\
\hline Years@ reduced capacity & $>4$ & $>6$ & $>1$ \\
\hline \multicolumn{4}{|l|}{ Storage pressure } \\
\hline Tritium pressure @ $100^{\circ} \mathrm{C}$, torr & $1 \mathrm{E}-6$ & 600 & 0.014 \\
\hline \multicolumn{4}{|l|}{ Charging conditions } \\
\hline Temperature, ${ }^{\circ} \mathrm{C}$ & 25 & 25 & 25 \\
\hline Pressure, torr & $>1$ & $>500$ & $>1$ \\
\hline \multicolumn{4}{|l|}{ Discharging conditions } \\
\hline Temperature, ${ }^{\circ} \mathrm{C}$ & 600 & $>150$ & 450 \\
\hline Pressure, torr & $<40$ & $<800$ & $<700$ \\
\hline Exchange required & yes & yes & maybe \\
\hline \multicolumn{4}{|l|}{ Safety } \\
\hline $\begin{array}{l}\text { Fresh powder igition temperature } \\
\text { in air, }{ }^{\circ} \mathrm{C}\end{array}$ & 420 & $\sim 50$ & 20 \\
\hline $\begin{array}{l}\text { Temperature excursion when air } \\
\text { leaks into vessel },{ }^{\circ} \mathrm{C}\end{array}$ & $<1$ & $<10$ & $<100$ \\
\hline
\end{tabular}


Figure 1. Desorption Isotherms Of The Titanium-Hydrogen System (Reference: W. M. Mueller, "Metal Hydrides", Academic Press, NY 1968).

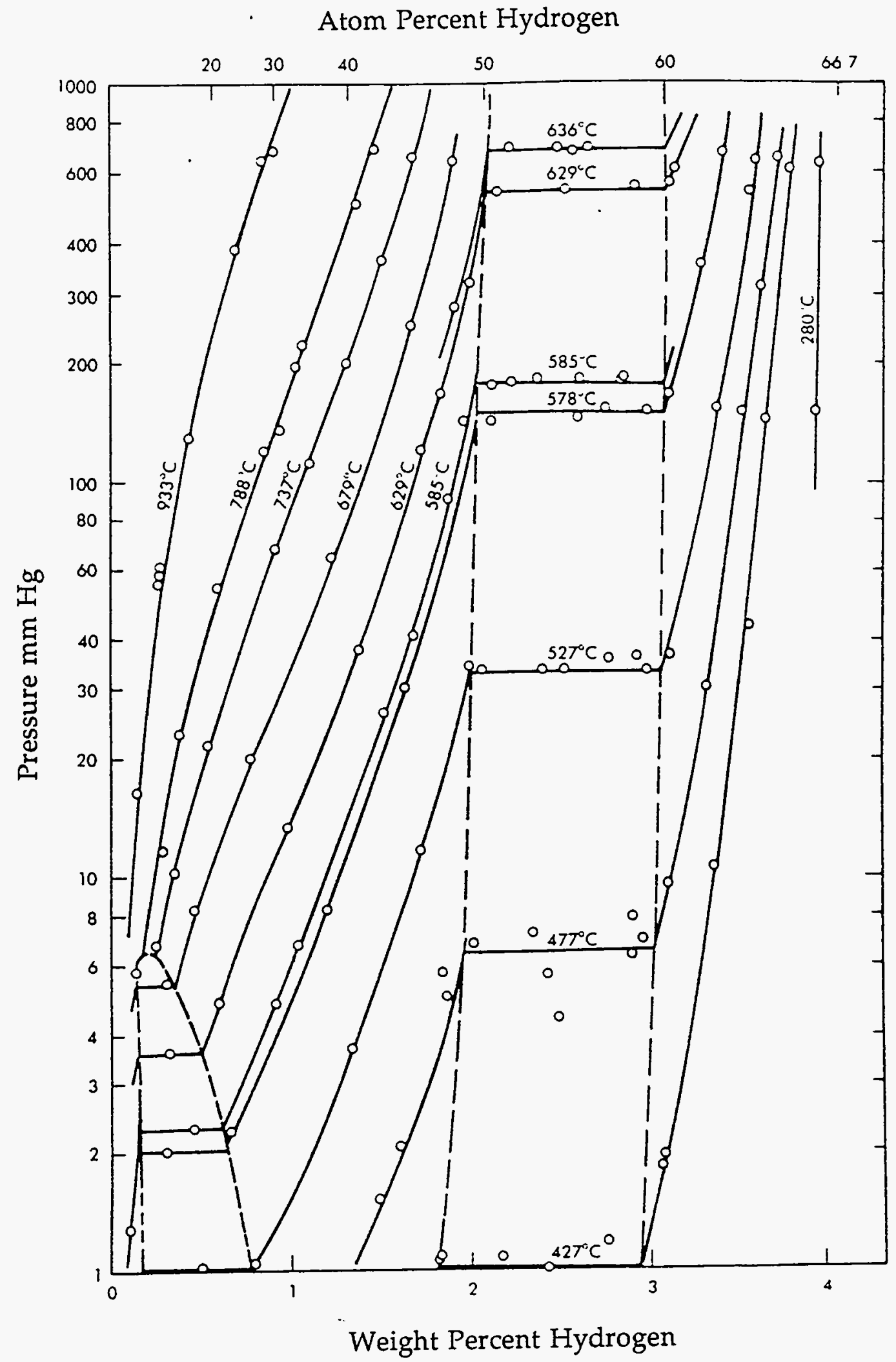


Figure 2. Desorption Plateau Pressure Of The Titanium-Hydrogen System (Reference: Derived from data in W. M. Mueller, "Metal Hydrides", Academic Press, NY 1968).

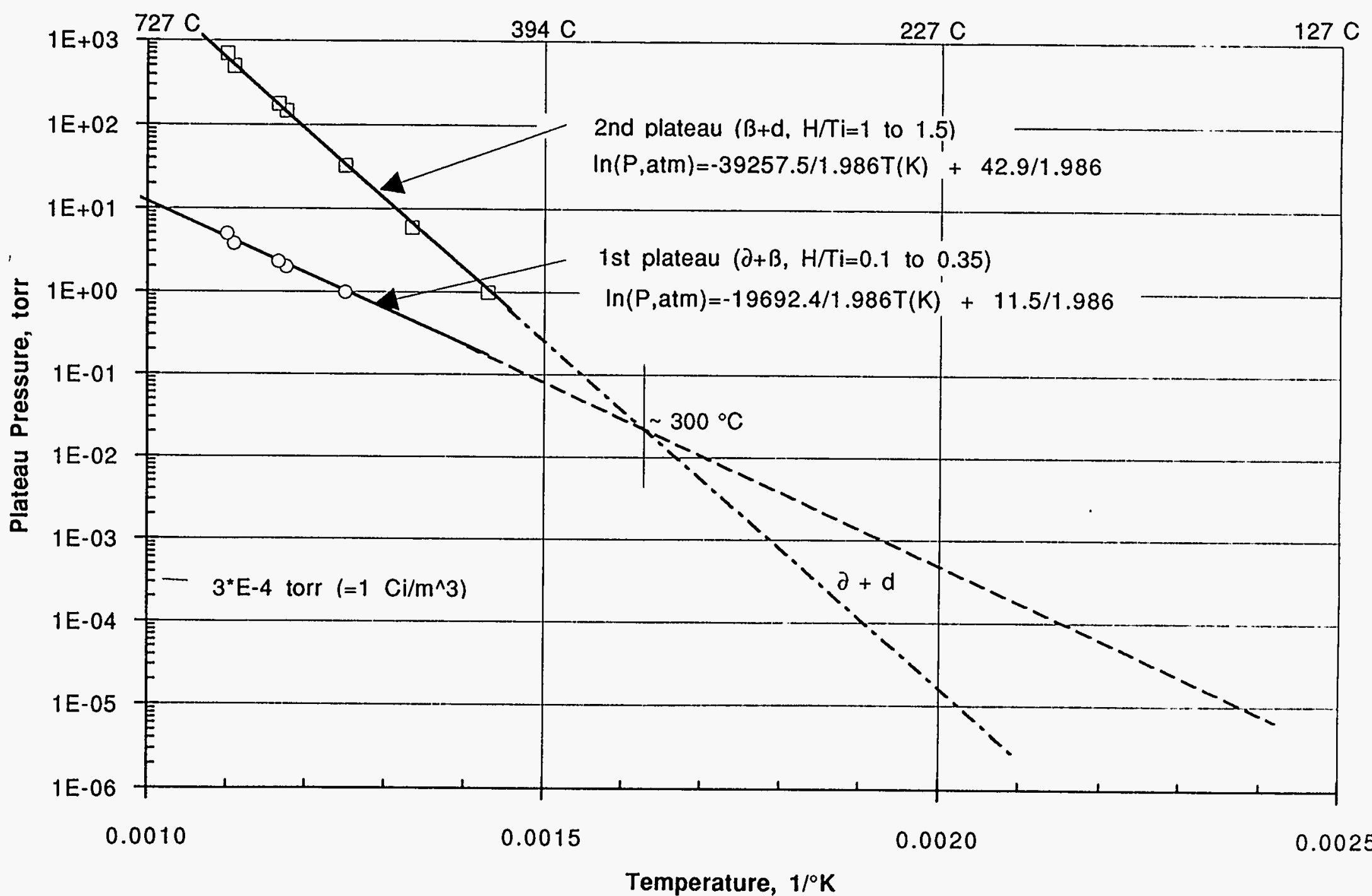

Reference: Data derived from W. M. Mueller, "Metal Hydrides", Academic Press, NY 1968. 
Figure 3. Schematic of Vessel Design For Long Term Tritium Storage Using Titanium.

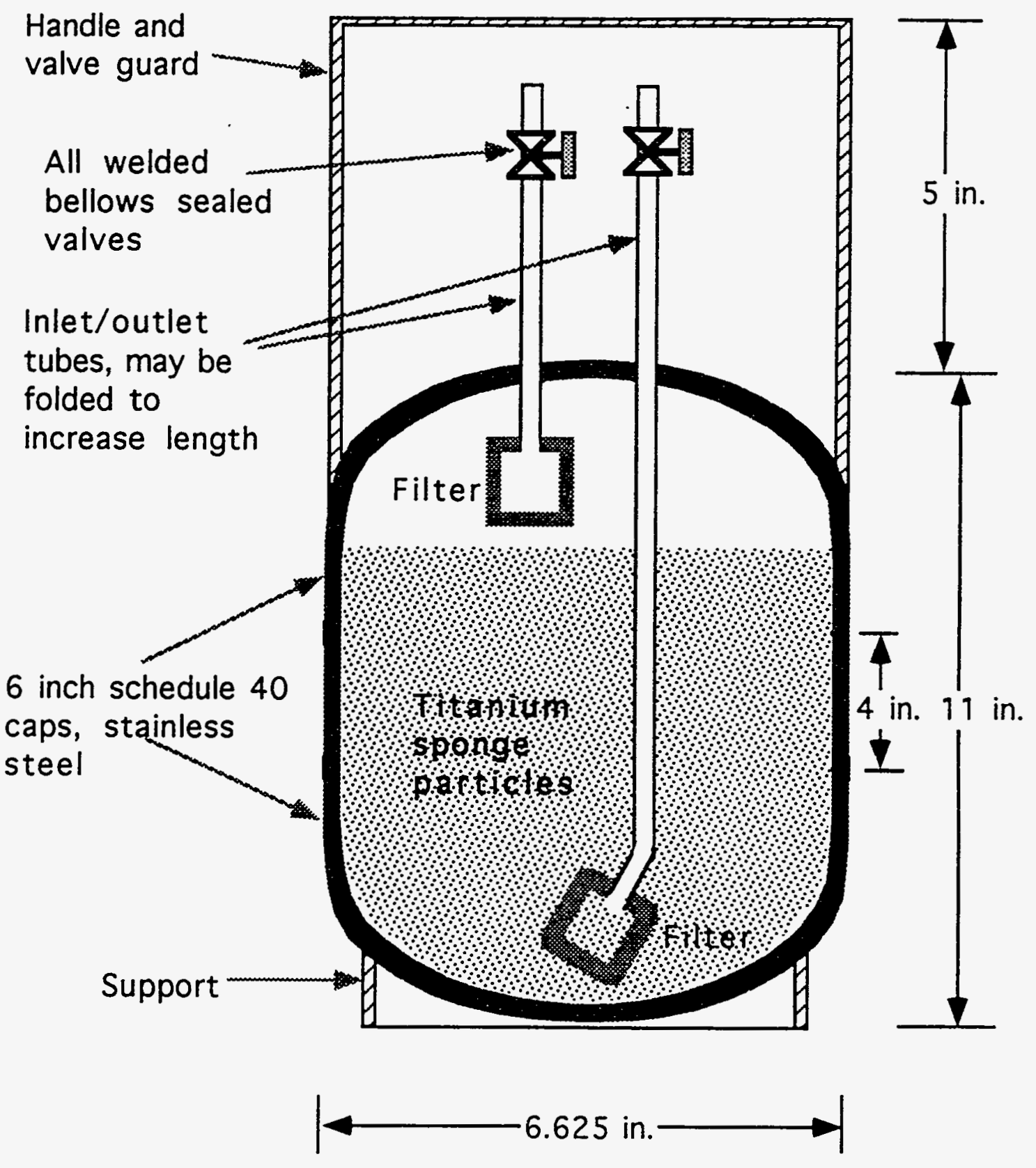

